\title{
Characterization of Clays and Clay-organis: Complexes
}

\author{
Raúl P'óréz liscolar'
}

\section{INTRODUCTION}

Clay-minerals investigntions have produced strong evidenes of somes sort; of reaction between the component parts of clays and organic malter. fundamental shanges in the nature of the reactants like, for instance, decolorization of oils when in conbat with clitys, and variation in the oplical properties of the clays, have inspired scientists to sary out hurther studies in an atempt to determine possible bond mechanisms responsible for sueth changes.

In the present study an efforl was made to determine the mature of linkages, if any, between blackstrap molasses, distillery slops, and slops active residue and soil colloids extracted from Evesboro, Whippany, lie, and Guániea soils. (To is not an iron soil; this word means "Taith" in Tinglish.)

\section{REVIEW OF TILE LITERATURE}

Hunt $(9)^{2}$ examined 15 different clay minerals using infrared rays and found that each had absorption bands characteristic of the individual clay mincral. In all elays a common strong band was found in the 1,100 to 900-cm. ${ }^{-1}$ range. He suggested the use of this tool as an aid in identifying clay minerals.

In 1957 Holmes and Toth (8) postulated the existence of a Si-()-C link occurring with kaolin at extremely high concentrations of S-17. They considered this bond to be of special significance sinee the carbon of this linkage is not carbonyl carbon.

Michaels and Martin (10), working with montmorillonite and illite, noted a marked increase in bonded OH and a corresponding decrease in free $\mathrm{OH}$ bonds. Considering the relatively small number of $\mathrm{OH}$ groups in montmorillonite, it is bolicved that the dotection of linkages of this type is rather difficult to observe.

Brydon and Sowden (3) have shown that amino groups are in many instances involved in the reaction between organic matter and soil mineral constituents. Others (7) have shown that organic eations, such as those containing the amino group, will be adsorbed at calion-exchange sites by montmorillonite. Soil-conditioning chemicals being anionic in nature, have

1 Associate Soil Scientisl, Agricultural Experiment Station, University of Puerto Rico, Río Piedras, P.R.

${ }^{2}$ Italic numbers in parentheses refer to Literature Cited, p. 315. 
been shown to potect soil aggregales against dispersive foreces. X-ray work has defintely shown that organie anions do not enter the intertamellat spaces of expanding lattice clays, and this has fod to the suggestion that organic anions are atsorbed on, and form bridges betwen the edges of elay aystaks.

Hoffmamn and coworkers (y) showed that the (C-axis dimension of montmorillonite varied following treatment with alcohol, acetone, and ether. Ensminger and Geiscking (/) showed that organic ions could be sorbed on the basal plane surfaces of montmorillonite. This suggested that orgunic compounds with polar-ative gromps ('ould be adsorbed by chy mincrals.

Soveral organic calions are known to contain basic amino groups. It is the reaction between these compounds aud the clay minerals that has been st.udied in greatest detail. Hendricks $(6)$ found that some of the organic ions studied were oriented buween the montmorillonite layers in such a way as to eause mininum expansion of the layers. This adsolption between the layers is known to render the organie compounds quite resistant to microbial degradation. The adsorption of organic ions also changes the properties of the clay mineral and, for example, swelling is greatly reduced.

\section{MATERIALS AND METHODS}

Intrared absorption analyses were made of selected samples using a double beam Perkin-Elmer, solf-recording infrared instrument. Sodium chloride prisms were generally used, but Irtran was used when the samples wore disporsed or dissolved in water.

'The clays used in these deterninations were those isolated from Gutuica clay, Fe clay, Whipparty clay, and livesboro loamy sand, all pootly drained soils. Two mieron-sized chays were separated by sedimentation.

Comploxes were prepared by reacting 9 parts of elay to 1 part of slops, or with molasses, or with clay-slops active residue. Spectra of the clays and those of the slops, molasses, and slops active residue complexes were all examined. Nujol ${ }^{3}$ was the material used to mull the clays and clay-organie malerial complexes. Corrocion for the peaks due to Nujol were made on most spectra.

Since montmorillonite was the dominant clay mineral in the elay fraction of both Gúnica and Fe soils (figs. 1 and 2), and sineo both molasses and slops are known to contain amino groups, an effort was made to determine whether a shift in the 001-spacings could result from the adsorption of these materiak. $X$-ray diffruclion spectroscopy studies using an RCA-Leiments crystalloflex IV X-ray diffraciometer were made on samples

${ }^{3}$ Trade name used to provide specific information; this does not imply endorsement or recommendation. 


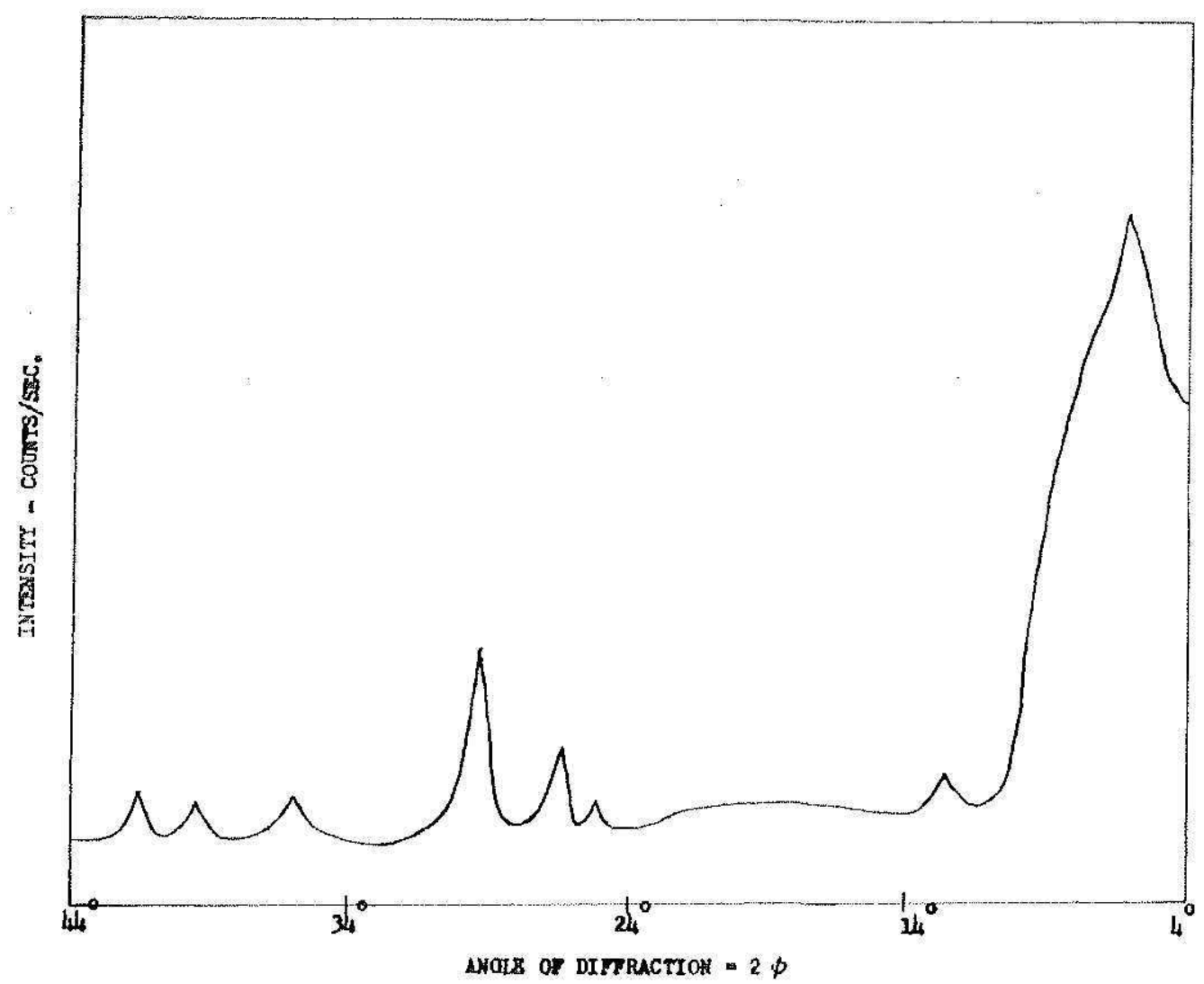

Fra. 1.-X-Xay difrantogram of day lration of (iuanica soil.

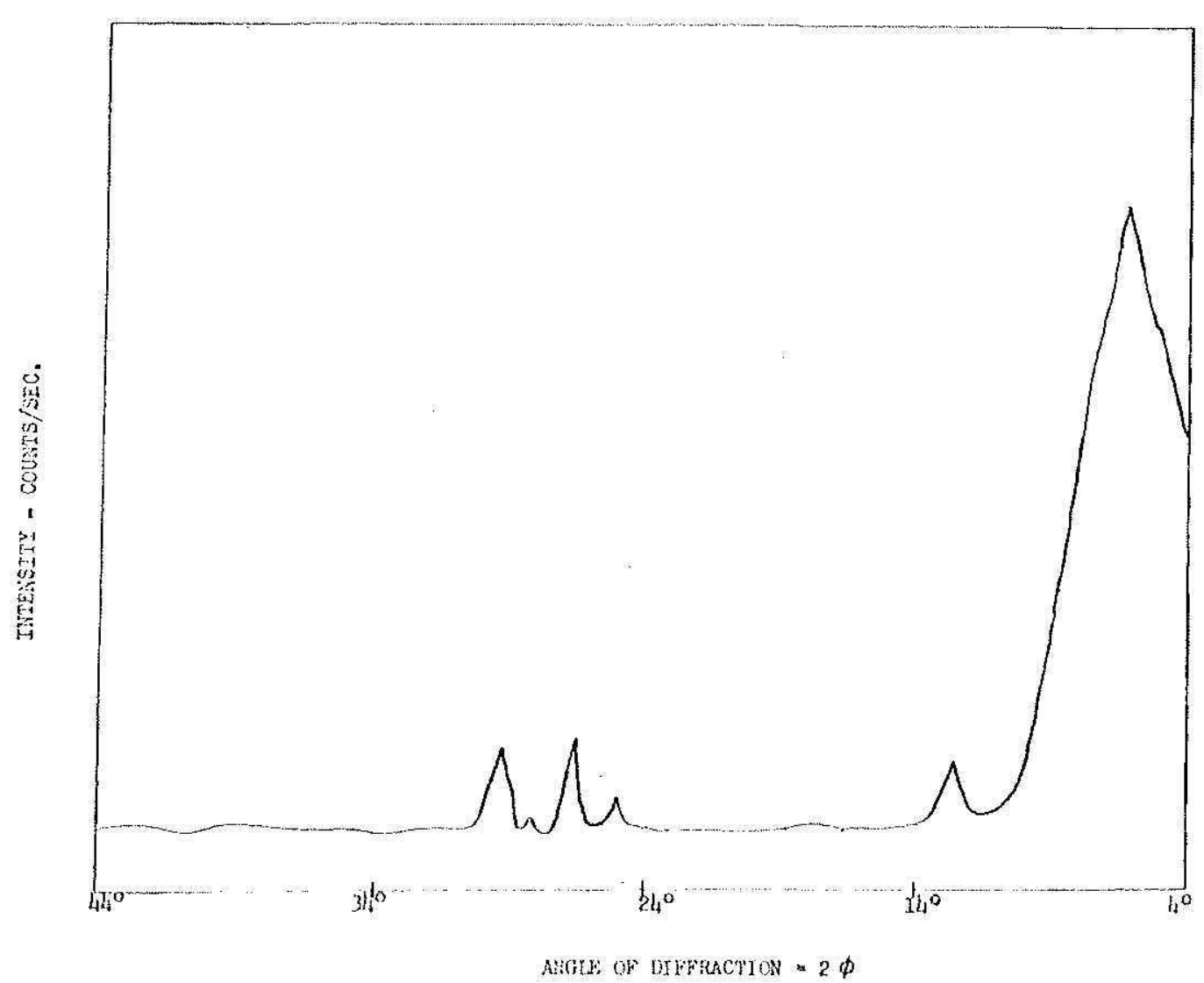

Fic. 2.-X-riy diffractogram of clay fraction of Fe soil. 
mounted as thin films on gliss slide. 'The slides were mounled in a sampleholder and scamued on the diffractometer through an angle of $3^{\circ}$ to $9^{\circ}$, since it was intended to determine whether a shift occurred in the 001spacing. In order to eheck the X-ray difraction studies, different levels of

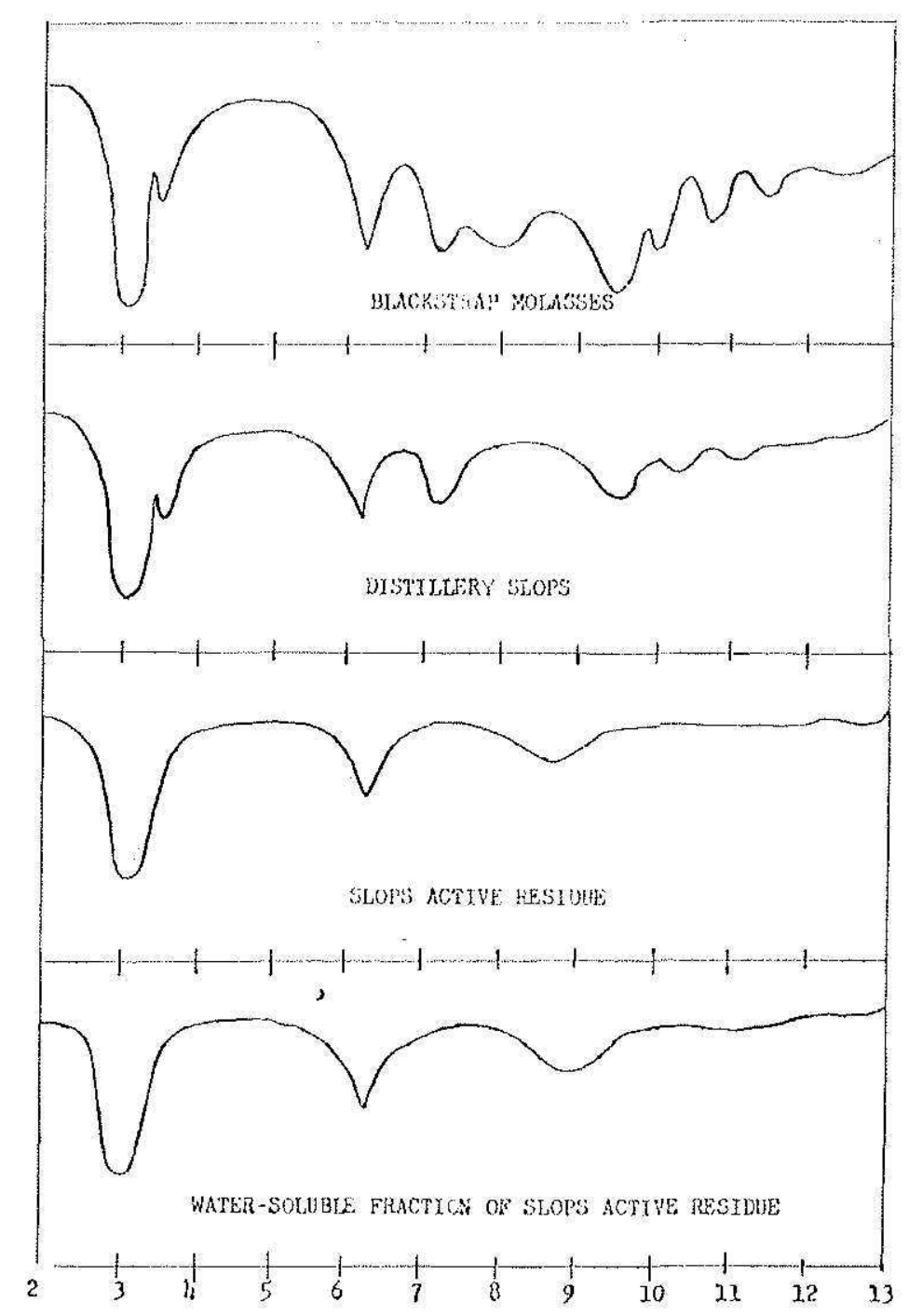

WMLLEGTH IN KICHOWS

Fra. 3.--Tnfrared spectrat of the organic materials.

slops were brought to equilibrium with a known amount of soil of both Guánica and Fe clay. Cation-exchange capacity was determined in them hy the sodium-acetate method (1).

\section{RESULTS AND DISCUSSION}

'The spectin of the slay fractions of these soils are presented at the top of figures 3 through 7 . All clays except the fraction isolated from the Evesboro 
soil showed the presence of unbonded OH groups. These bunds appenred in the region of $2.75 \mu$. The bonded hydroxyls caused a marked absorption in the $3 \mu$-region of all four elays studied. The somewhat pronounced peak at $6.1 \mu$ has alrealy been assigned to adsorbed water. The peaks at 6.90

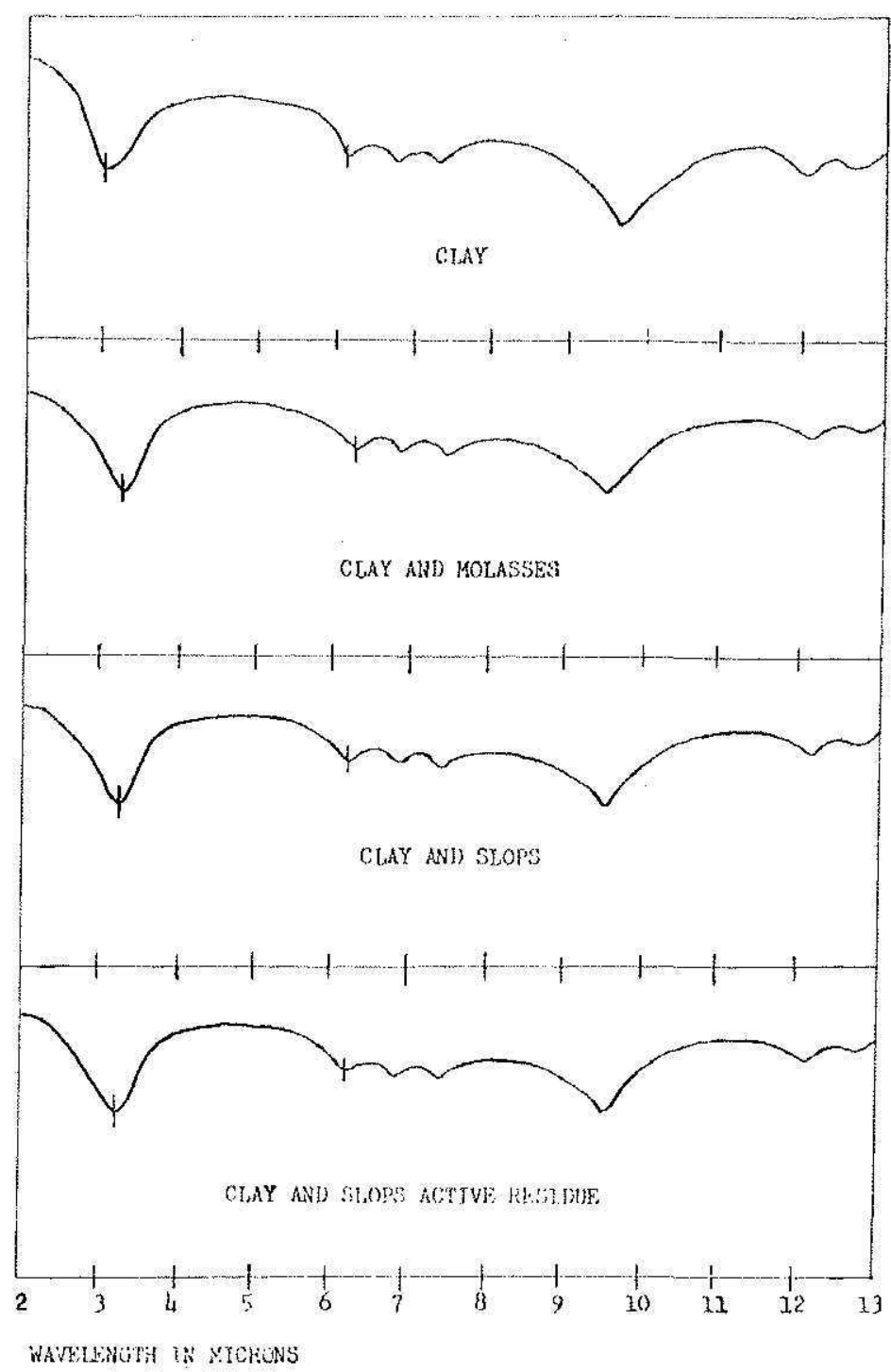

FI(i, 4.- Infrared spectra of the clay fraction of Evesboro soil and clay-organic complexes.

and $7.2 \tilde{5} \mu$ resulted from $\mathrm{CH}$ vibrations of the mulling material used, namely, Nujol. Since the silica tetrahedra and aluminum octahedra we common to all clays, vibrations attributable to these structural entities were found in the four clays exanined. These appeared in the region of $9.70 \mu$. Only the clay fractions of the Whippany and Evesboro showed octahedral OH stretching vibrations at $10.95 \mu$ whereas the chy fractions 


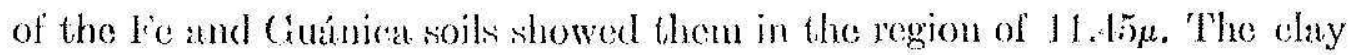
fractions of Whippany und livesboro soils showed rather wenk absorption peaks at 12.55 and $12.85 \mu$. These bave not yet been identified.

The spectra of blackstrap molasses, distillery slops, and slops active

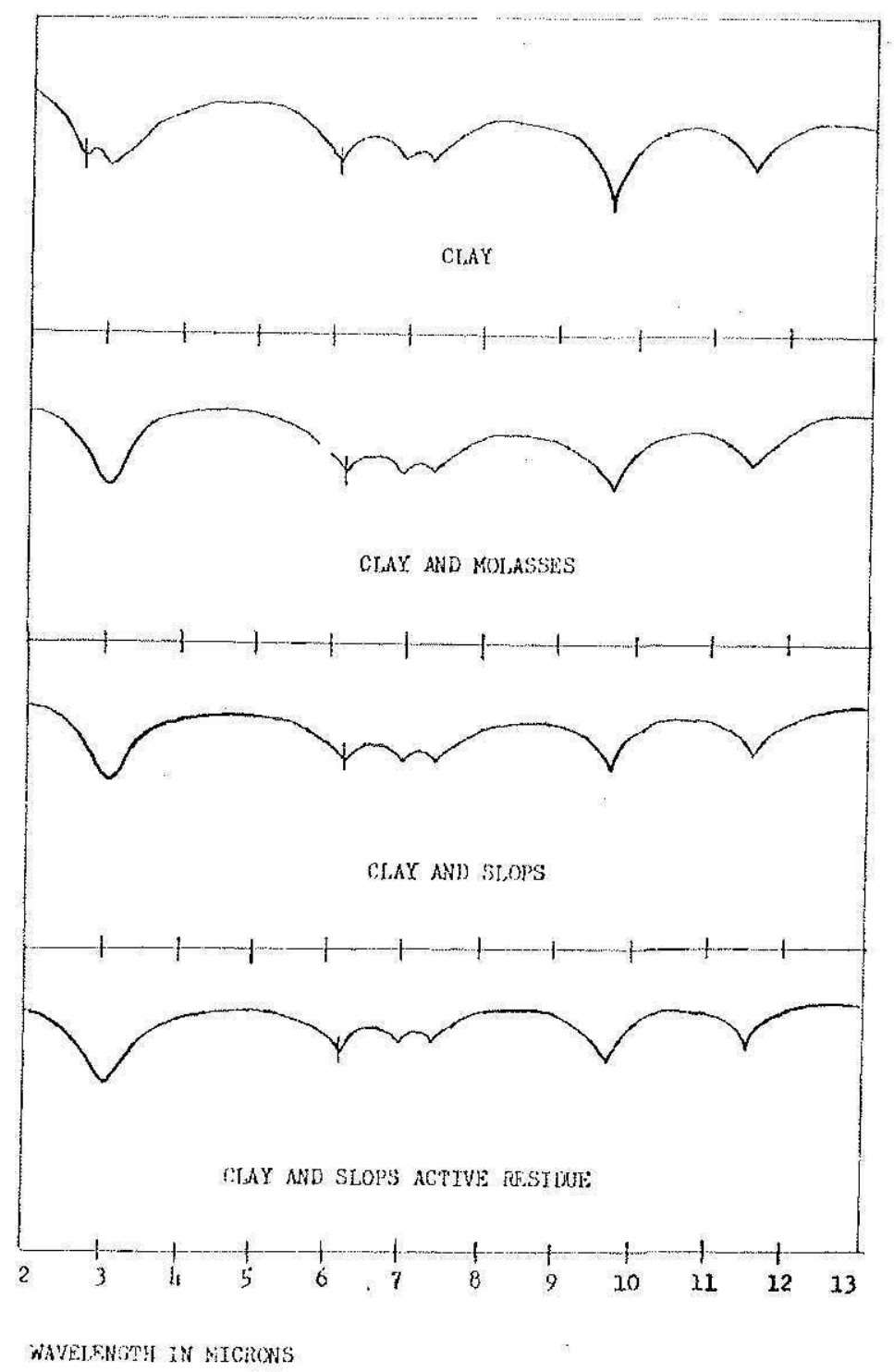

Frc. 5. - Infrared spectra of the elay fraction of Whippany soil and elay-organie somplexes.

residue are showu in figure 3. The very strong absorption peak in the 3.0i)- $\mu$ region is due to free OH. 'The sources of this functional group are water and sugars. The rather sharp peak at $3.45 \mu$ is believed to be characteristic of the $\mathrm{CH}_{3}$ group of organic acids present in the molasses. The 
absorption in the region of $6.2 \mu$ is related to the presenee of amino groups characteristie of amino acids, polypeptides, and proteins. The broad and strong peak shown in the region of $7.10 \mu$ is also characteristic of ionized carboxyl groups. Several investigators (5) have aftributed this peak to the

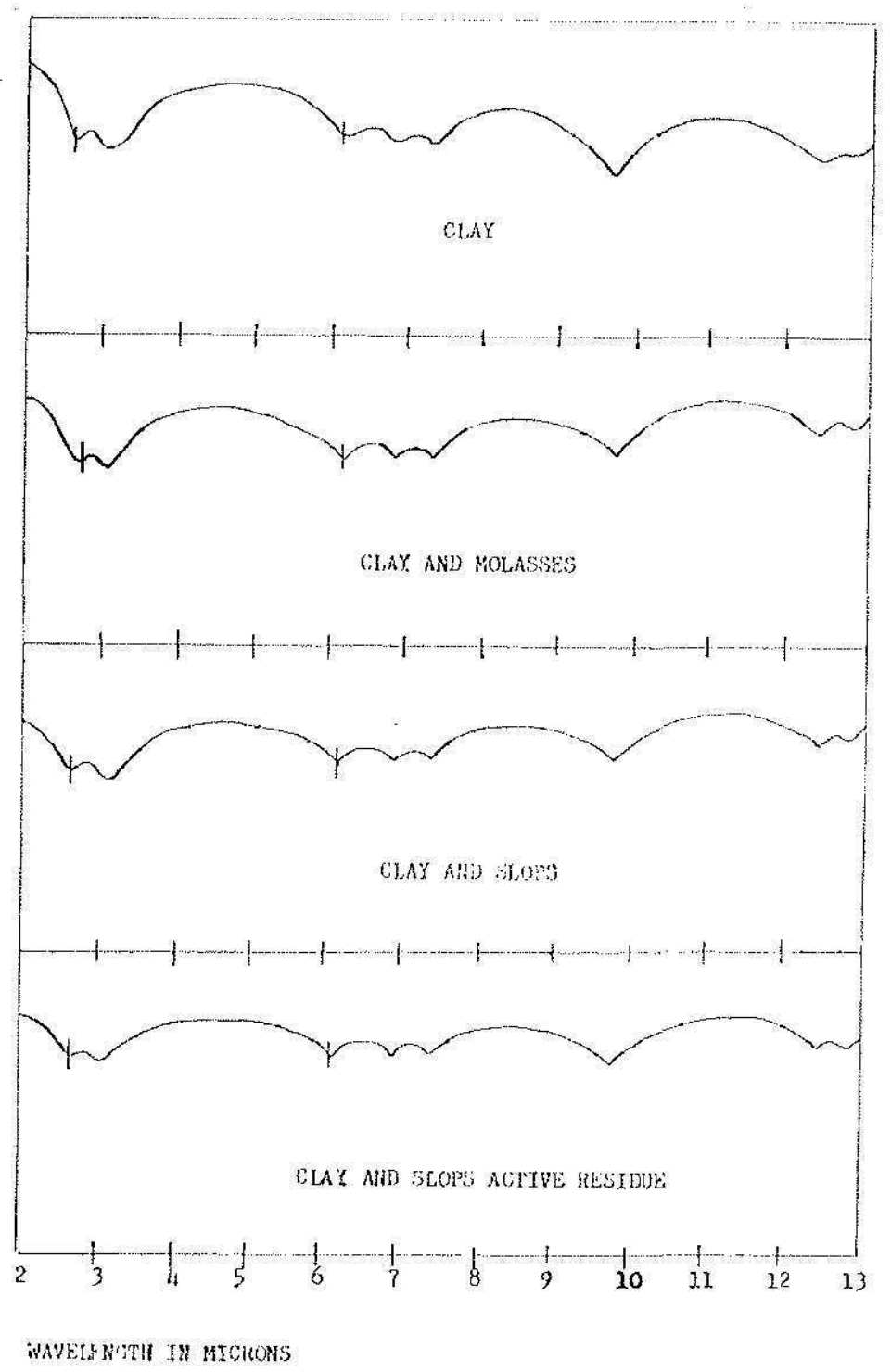

Fiti, 6.- - Infrared spectra of the elay fraction of fie soil and clay-organic complexes.

presence of methoxy groups (-O- $\left.\mathrm{CH}_{3}\right)$. Browne and Phillips (2) roported the presence of these groups in sugarcaus juices and the blackstraps molasses. The broad bamk between o to $10 \mu$, with a peak at 9.5 $\mu$, are probsbly (aused by $\mathrm{CH}, \mathrm{COOH}$, and $\mathrm{C}=\mathrm{O}$ ) ketonklohyde groups. The peaks 
arising in the regions of 10.05 and $10.80 \mu$ are probably produced by $\mathrm{CH}_{2}=\mathrm{CH}_{2}$ and $\mathrm{COOH}$ groups.

The spectrum of the slops shows essentially the same pattern as that of

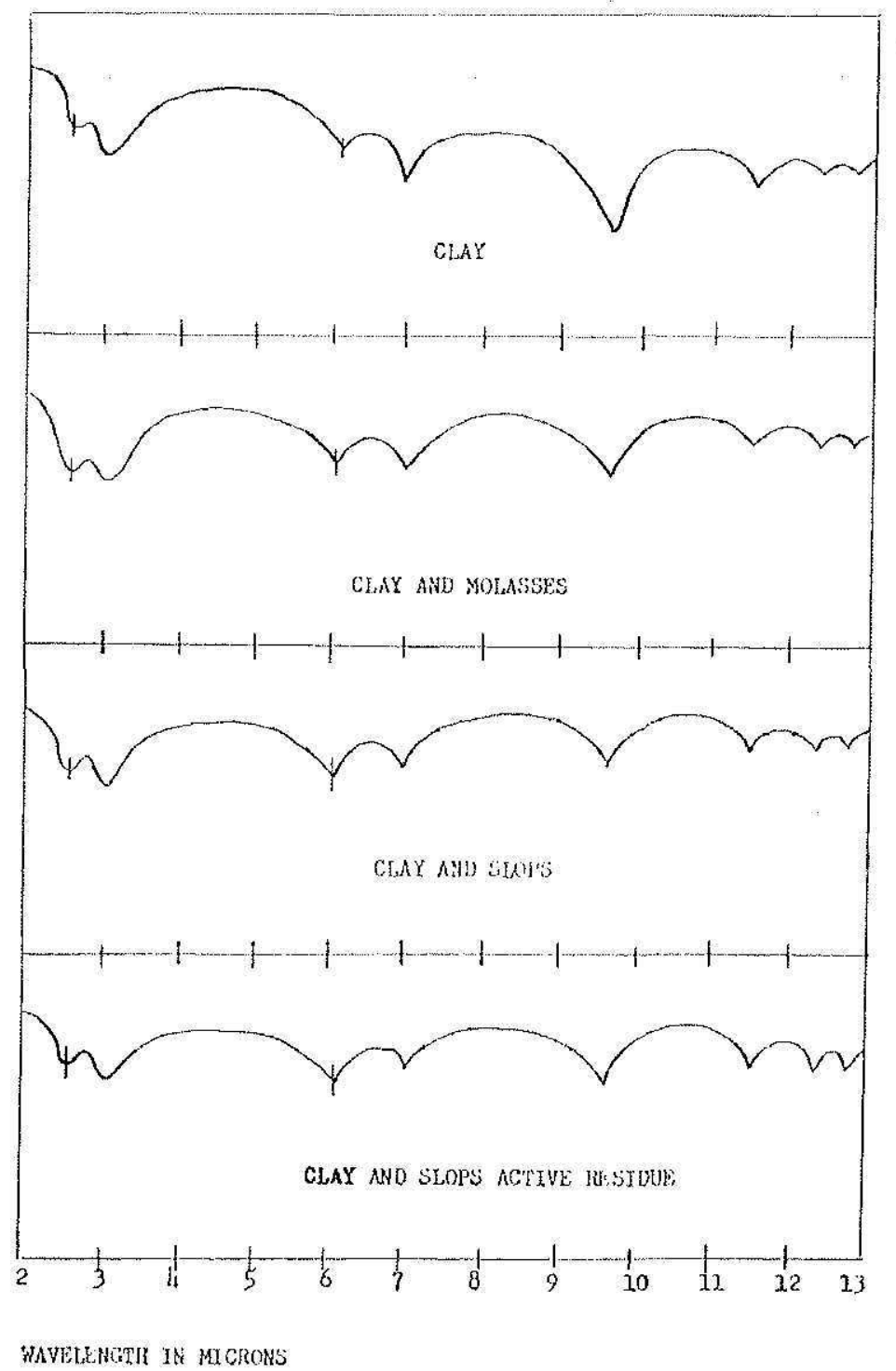

Frti. 7.- Infrared spectra of the elay fraction of Guánica soil and clay-organte complexes.

the blackstrap molasses, except that the peaks in the region of 10.05 and $10.80 \mu$ noted in molasses are absent in the slops spectrum.

The spectrum of the slops active residue (12) is somewhad different from

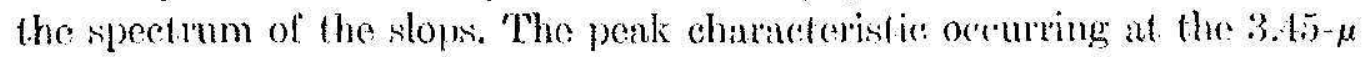
region ean hardly bo detected. The absorption peak at $7.1 \mu$ has virtually 


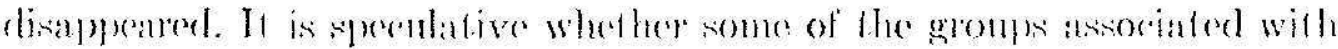

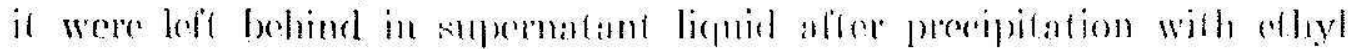
atrohol, or whether hythogen-fomeling oremere to the extent that only at

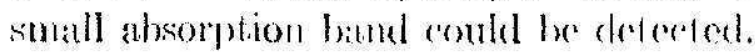

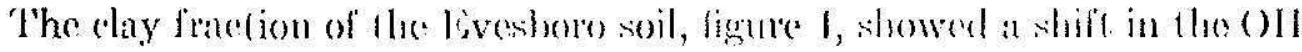
position from the 3.00 to $3.05 \%$, indiating that the exposed ()H of the arystal edge was bombed to the blakstlap nolases by way of a bydrogen bond. Another linkage of the same type wats observed when the 6.1 vibrafion of the clay shiffed 0.05$) \mu$ towat a region of longer wavelengih. There was no difference betwen the linkages oesturing in this clay fration romplexed with molasses, slops, and slops andive residue.

When the clay fraction of the Whipmany soil (fig. 5) wats complexed with the thee organie materials, only hydrogen bonding by means of the free hydroxyls was fouth in the $2.80 \mu$ regions. Strporisingly no linkage could be detected for atiorbed water.

Figure 6 shows the same fype of bonding oreurring when the clay lrac:tion of the fe soil was romplexed with the various organic matexials. When the clay fraction of the Gubinica clay was complexed with molases, slops, or the slops antive residue, no bonding orrumed, as shown by the spectrum in ligure 7. It is worthwhile to point out that the pH of this soil was 9.0 which should not have favored the formation of a linkage. As pointed out elsewhere (11), neither blakkstay) molassos nor distillery slops wero effertive in stimulating aggengte stability in this soil tunless arid ronditions were created by mo:us of sulfur applications.

To summarize, it is apparent that only H-bonding, through the exposed ()H of the elay arystal, is operative between the organie nuterials tested and elays isolated from the Evesboro, Whippuny, and fie soils. The linkage is probably via the carbonyl groups in the orgunic materials. A shift, however, in the peaks of the COOH groms was not observed, sinee the organir materials could not be properly nulled with Nujol. The complexes could not be rum in Irtran because the scattering of the infrured rays was such that practically all the enexgy was lost.

Whether hydrogen bonding is of any signilieanee is primarily dependent on the number of hydrogen bonds formed. These bonds are known to be relatively weak in nature, but, if sufferent numbers are present, their sums will be large.

In a heterogeneous system, surb as exists in soil colloich, blocking of cxchange sites berause of the presenee of primaty formation will reclue the number of potential linkage sites avatable for reaction. This means that the adsorption of potentially reactive organic substances will be reduced, and may therefore be subjected to breakdown by micro-organisms.

Since it was shown earlier that montmorillonite was the dominant clay 


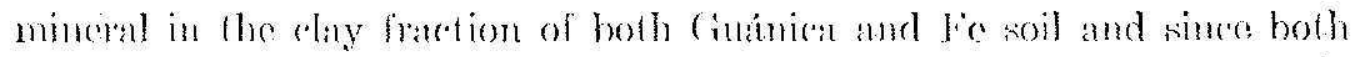
moliswes and slops are known to contain anino groups, au effort was made to retermine whether a shift in the 001 sparings ende result from the artsorption of these materials.

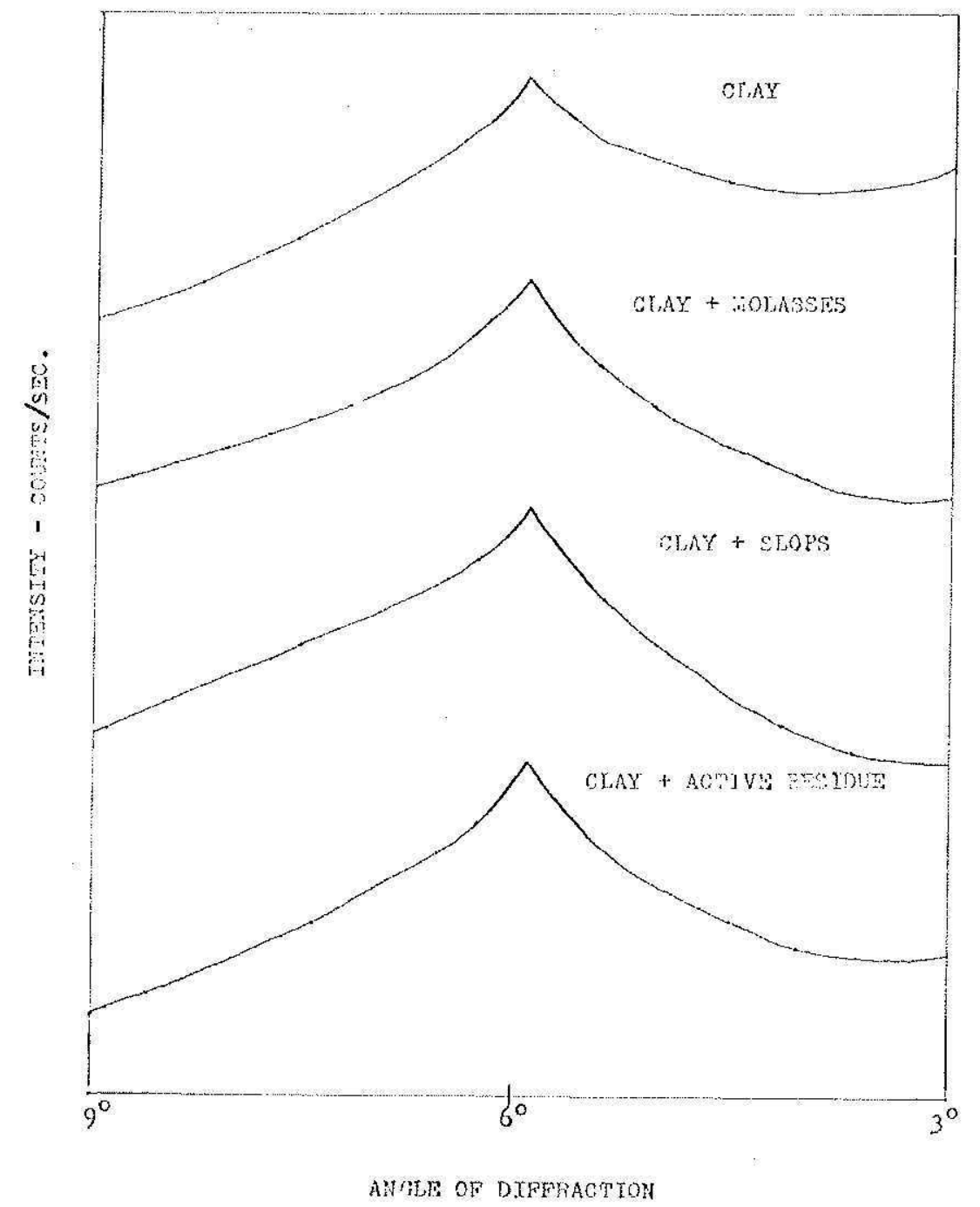

$2 \phi$

Fra. 8.--X-ray diflactograms of the clay fanetion of Fe soil and clay-organic complexes.

X-ray sudies showed that no changes resulted from adsorption of molasses or distillery slops between the basal planes of the elays, figures 8 and 9 . It seems ats if the size of the molecules found in the slops and nolikses is such that they will not fit between the 001 planes. As shown by the infrared absorption-spectrum data, hydrogen-bonding is proposed for the 


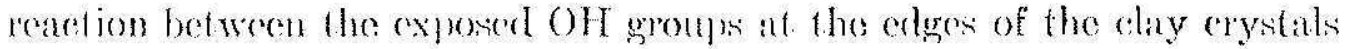
and these materiak. This implies that tho active enstituents of these wo organic: substances are not proteded by the clays to a great extent, and their lasting effere in the soil depends entirely on their resistance. Microbial

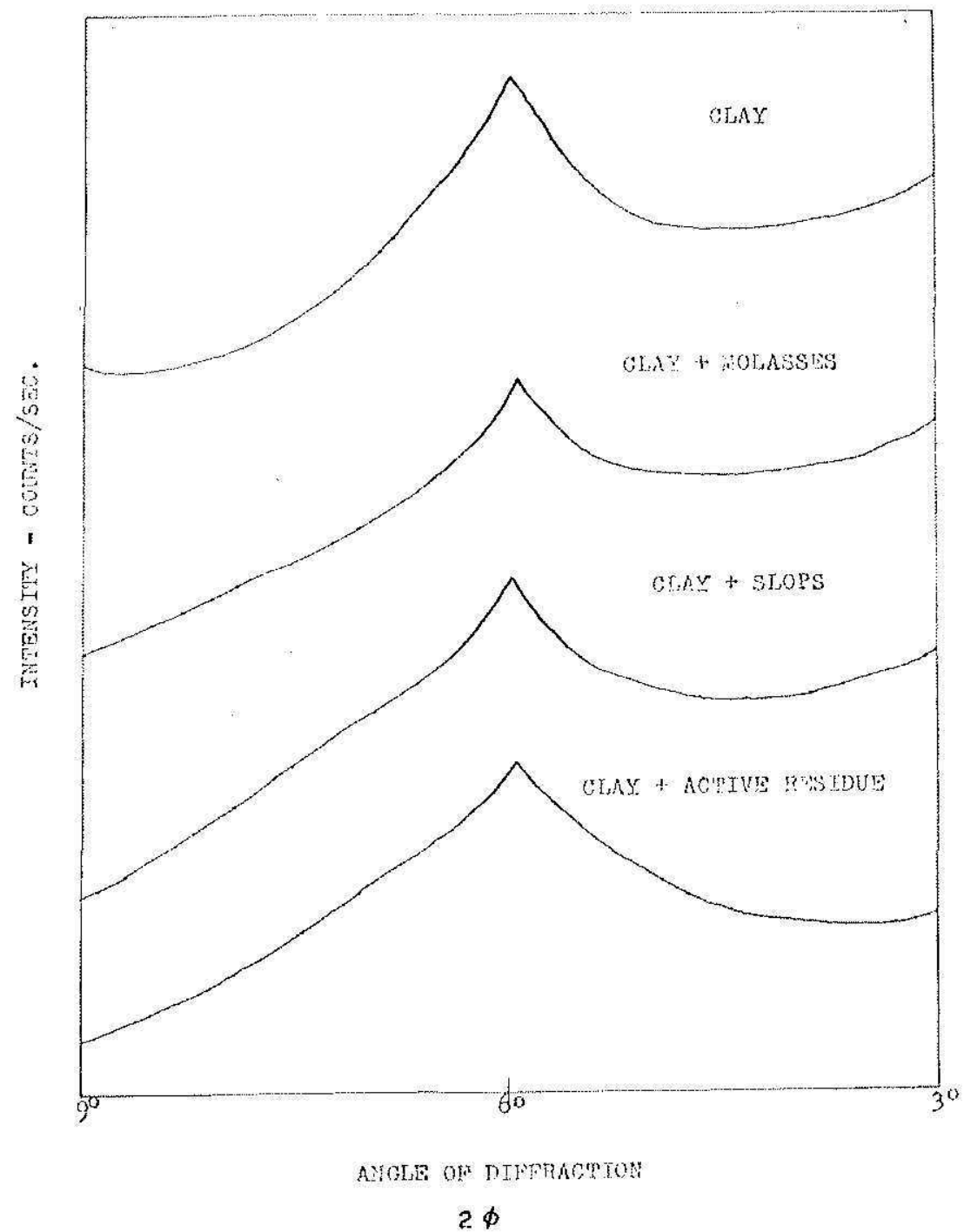

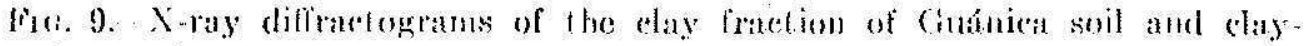
argathic complexes.

decomposition is preceded, however, by the production of euzymes which hydrolyzo organic: malter. These enzymes have specific isoelectrie points and can be adworbed by the rays with expanding lattices and rendered inselive. Inder these rontitions little decomposition of the organic day aggrogating matcrial would ocerul. 
A very slight increase in mion-exchange muncity was found to oceur mpon emplexing the clays of fer and Guanien soils with slops. This is shown in table 1. Reductions in whion-exchange calpacity have been ustally found to oceu when some peoteins are adsorbed by the expanding clay lattice minerals.

T'Aвнt: 1. Elfeel of distillery slops on culion-exchange capacity of the Guaniea and l's soils

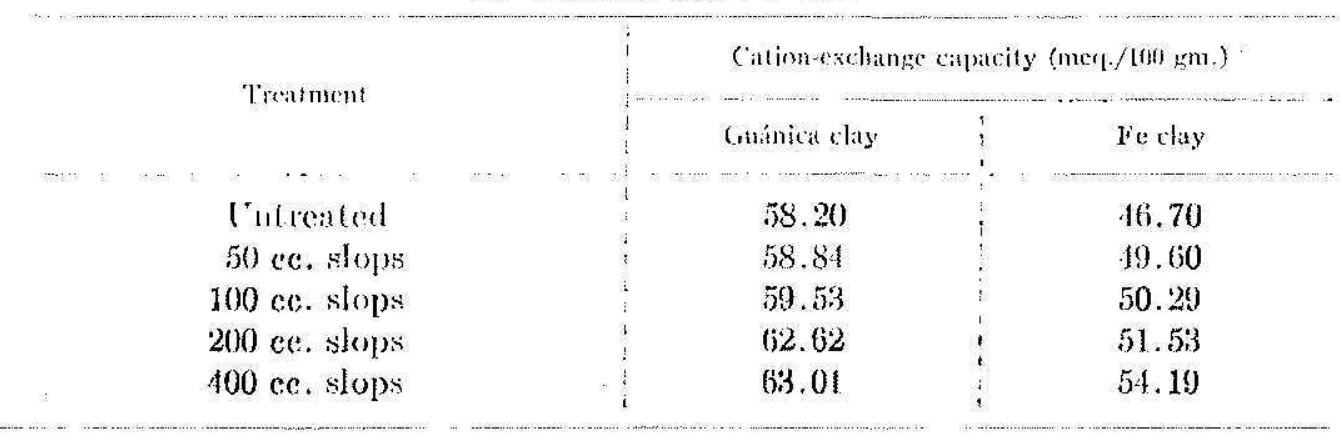

\section{SUMMRAR}

Intornation is presented with reforence to the inleured spectoscopy of blackstra\}) molasises, rum clistillery slops, the active fraction of the slops, chays of four poorly drained soils, and of the conplexes formed botween organie materials and the clays of Fe, Guanim, Whippany, and Lvesboro soils. The X-ray spectrosenpy of two of the clays of montmorillonitic nature and of the emplexes formed with the organic malerials is also shown.

Characteristic peaks of the orgatuic materials inclucle those aused by hydroxyl, methyl, amino, methoxy, atrbonyl, and ketonic groups.

The speetra of the elays showed poaks which are attributed to hydroxyl, bonded and unbonted, adsorbed water, silien lotrahedra, and aluminum octabodra.

Hydrogen-bonding oreured between the exposed hydroxyl groups of the chy crystak and the molasies, slops, and its active residue. There was no shilt in the $2 \phi$ angle of diffration of the expanding-lat tice clays, indirating that there was no adsolption in the interlamellar spuces. The actsorption was possible at the edges of the erystal. This finding was strengthened by the fact that rather than undergoing a decrose in cation-exchange (aparity there was a slight increase in the expending lattiec clays.

\section{RESUMEN}

Gin este trabajo se informa sobre la espectroseopia infraroja de la miel final, del mosto y su residno acelivo, de las arrillas de cuatro snelos de mal 


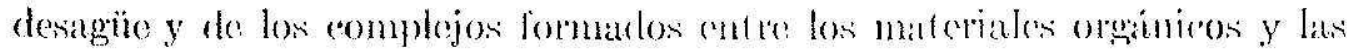
areillas de los suelos Fe, Ciuanica, Whippany y Evesboro. También, se incluye la espectroseopia, por medio de los rayos $X$, de dos de las arcillas de naturaleza montmorillonítica y de los complejos formados con los materiales orgénicos.

Jos picos caractertsticos de Jos materiales orgúnicos incluyen los quo rorresponden a los grupos de los hiclroxilos, los metílicos, amóniesos, mefóxi$\cos (\mathrm{O})-\left(\mathrm{CH}_{3}\right)$ y retónicos.

El espectro de las areillas reveló piros propios do los hicloxilos, sin enlakar y enlazados, del agua adsorbida, de los de temahedro de síliro y do los ale octahedro de aluminio.

So determinó la presencia de colaces de hidrógeno entre los hirboxilos extermos del eristal areilloso y la mirl, el mosto y sul residuo activo. No hubo cambio en el ángulo $2 \phi$ de difracción de las areilas que se expanden, indicando que la adsorción de los materiales orgánicos turo lugix en el exterior del eristal areilloso y no entre las lanelts.

\section{HITERATURE CITHO}

1. Bower, C. A., Reitmeier, R. F., and Eiremau, M., Fxchamgeable ention analysis of saline and alkali soils, Soil Sci. 73; 251-41, 1952.

2. Browne, C. A., and Phillips, M., Methoxyl and uronic acid content of the sugarcane and of the juices amd molasses derived therefrom, bal), int., Sugar of. 4t: $430-32,1939$.

3. Brydon, J. Li, and sowden, F. J., $A$ study of the elay-humus eomplexes of a rbernozemic and a pedzol soil, (an. J. Sorl Sci. 39: 163-43, 1950.

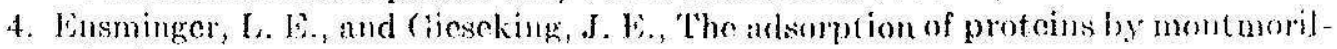
lomite clay, Soil Sci. $48: 467-73,1939$.

5. Famer, V. C., and Marison, R. I., Chemical and infrared studies on phragmites peat and its humid acid, Sci. Proc. Royle Dublin Soc. (4) : 85-104, 1960.

(i. Hendricks, \$. B., Base exchange of the clay mineral mounorillonite for orgunic cation and its dependence upon adsorption duc in Vander Wats forces, $J$. Phys. Chem. 45: 05-81, 1941.

7. Hoffman, V., Endell, KS., and Wilm, J). Rontgenograplusche and kollodedhemische unt ersuchunguenuber ton, digfu. (.kem. 47: 539 47, 1934.

b. Holmes, R. M., and Tolh, S. J., Physico-ehemieal bohavior of clay-conditioner complexes, Soil Sci. 84: 479-87, 1957.

9. Hiut, J. M., Wisherd, M. P.; and Bonthm, L. C., Ini rared spectrat of minerals and ot her inorganie compoumels, Anol. Chem, 22: 1478-97, 1950.

10. Michaels, A. S., Agrregution of suspensions by polyolectrolyles, Ind. \& Eng. (.hem. 46: 1485-90, 1954 .

11. T'erez Jkeolur, R., Use of molasses and distillery slops in conjunction with sulfu. for the reclamution of a saline-sodic and a sodir soil from Puerto Rico. In preparation.

12. - - Separation and characterization of the ardive soil argregating agent present in distillery slops, (in preparatism). 